\title{
DEBUTS
}

Paul Fabel ${ }^{*}$

paul.fabel@posteo.de

Belziger Str. 16

10823 Berlin, Germany

\section{Due Diligence Obligations in the New German Cultural Property Protection Act}

\begin{abstract}
Chapter 4 of the German Cultural Property Protection Act (hereinafter: the "Act" or "CPPA") contains due diligence obligations of individuals as well as businesses that deal with cultural property. The aim of this contribution is to present the scope and requirements imposed, on whoever purchases or sells art, following the entry into force of the Act. In doing so, this article refers to the European Union Directive which led to the introduction of the new due diligence obligations in German law. The paragraphs of the Act are either introduced verbatim or paraphrased, followed by commentary. Wherever applicable, the arguments put forth by various actors in the art world are presented in order to demonstrate the different arguments from "both sides of the art market isle".
\end{abstract}

Keywords: Due diligence, Directive 2014/60/EU, cultural property, burden of proof, provenance

\footnotetext{
* Paul Fabel is a post-graduate student of International Relations (M.A.) at the Dresden University of Technology, Germany. He specialises in international protection of cultural heritage. The author would like to thank two anonymous reviewers for their recommendation and comments as well as the editors of this paper for considering this contribution. Special thanks go to Louisa Kimmig for providing invaluable feedback and counsel.
} 


\section{DEBUTS}

Paul Fabel

\section{Introduction}

Much has been done at the international, European and national levels with regards to legislation and policy implementation aimed at creating a cleaner art market and suppressing illicit trade in cultural property. By targeting both the demand and supply sides of the market, lawmakers have had to weigh protection measures against market values and property claims. Developments in recent decades have led to the adoption of rules that target whoever is active in the global art market and require them to engage in some degree of scrutiny into what he/she is about to sell or buy. At the same time, new laws have had to be imposed in order to guarantee a better provenance (and documentation) of any cultural item.

The most recent efforts include the new Directive 2014/60/EU of 15 May 2014, ${ }^{1}$ recasting the former Council Directive 93/7/EEC of 15 March 1993. ${ }^{2}$ One of the major modifications contained in the new Directive is the introduction of compulsory due diligence obligations, taken almost verbatim ${ }^{3}$ from the 1995 UNIDROIT Convention on Stolen or Illegally Exported Cultural Objects. ${ }^{4}$ Article 10 of the Directive 2014/60/EU shifts the burden of proof from the seller to the buyer of the cultural object(s) in question. This should ultimately enable the competent (national) court to grant just compensation to good faith purchasers if they can prove their adherence to these requirements.

The German Cultural Property Protection Act ${ }^{5}$ (CPPA) takes a slightly different approach than the UNIDROIT Convention or the 2014/60/EU Directive's original intention: it uses the term "Inverkehrbringen"6 (German: Verkehr - circulation; bringen - to bring, to introduce) and thus broadens the due diligence obligations, placing them upon whoever decides to "bring" cultural property "into circulation". The implications which these provisions can have, as well as the art world's arguments and reactions to it, are scrutinized in the following sections.

1 Directive 2014/60/EU of the European Parliament and of the Council of 15 May 2014 on the return of cultural objects unlawfully removed from the territory of a Member State and amending Regulation (EU) No. 1024/2012, OJ L 159, 28.05.2014, p. 1.

2 Council Directive 93/7/EEC of 15 March 1993 on the return of cultural objects unlawfully removed from the territory of a Member State, OJ L 74, 27.03.1993, p. 74.

3 Commission Européenne: Document de travail des services de la commission. Analyse d'impact, SWD (2013) 188 final, 128.

424 June 1995, 34 ILM 1322.

5 Gesetz zur Neuregelung des Kulturgutschutzrechts - KGSG [Act of 31 July 2016 Reforming the Law on the Protection of Cultural Property], Bundesgesetzblatt (BGBI.) 2016 I S. 1914, http://www.gesetze-im-internet.de/kgsg/index.htm [accessed: 21.09.2016]. The overall CPPA is a uniform law and comprises all necessary rules on protecting cultural property. It contains, as its Article 1, the Cultural Property Protection Act (CPPA), which implements the EU Directive 2014/60/EU. It is for this reason that the CPPA is comprised of paragraphs instead of articles, because it is in itself Article 1 of the overall legislative endeavour. The Act Amending the Cultural Property Law of 31 July 2016 entered into force on 6 August 2016. BGBII S. 1914. See also the article by R. Peters in this volume.

6 The legal definition of this term is presented in para. 2(1)9 CPPA. 
In doing so, I first sketch out the overall endeavour of the German legislator, then concentrate on the due diligence requirements in the said law. This part will be split into sections corresponding to the level of professionalism of the parties involved. After examining the implementation and legal consequences of the CPPA, the contribution ends with a summary of the main findings and offers some thoughts about the Act's potential effectiveness.

\section{Germany's approach to a legal, "cleaner" art market}

Until recently, only cultural objects that were listed as cultural treasures were protected under Council Directive 93/7/EEC, and could only be returned to Germany if illicitly (meaning without an export license) transferred to another EU member state. In order to profit from the broader protection of Directive 2014/60/EU, the scope of protected cultural objects ${ }^{7}$ is now - under the new German law - extended to public collections ${ }^{8}$ as well as object(s) of churches or religious entities. ${ }^{9}$ Furthermore, any cultural object designated as a "valuable cultural good"10 can be enlisted and receive the same protection. In order for it to be registered, it needs to be of fundamental value to German cultural heritage ${ }^{11}$ or its transfer out of Germany considered as a loss. ${ }^{12}$

Depending on age and value limits, export certificates must be obtained in order to legally transfer a listed cultural object (or one currently in the process of being listed) ${ }^{13}$ outside of Germany - regardless of whether the transfer is to an EU member state or a third state. ${ }^{14}$ If a permanent export license is issued, the object in question has to be delisted ${ }^{15}$ and no longer falls under the protection of either the EU directive or the CPPA. ${ }^{16}$

The law introduces value and age limits (see below), without changing stricter requirements such as the trade bans on Iraqi or Syrian property covered by EU regulations. Before the entry into force of this law, due diligence obligations were

\footnotetext{
7 The German term used in para. 5 CPPA is "Nationales Kulturgut", i.e. "national cultural good".

8 Different kinds of public collections are listed (para. 6(1) No. 2-4 CPPA) while at the same time excluding temporary loans of objects, if the lender explicitly so desires (para. 6(2) CPPA).

9 Para. 9 CPPA allows these entities to enlist their collections upon their wish and thus puts them under protection.

10 Para. 6(1) No. 1 CPPA.

11 Para. 7(1) No. 1CPPA.

12 Para. 7(1) No. 2 CPPA.

13 Para. 21 CPPA.

14 What had previously applied to transferring a cultural object outside of the EU (under the Council Regulation (EC) No. 116/2009 of 18 December 2008 on the export of cultural goods (codified version), OJ L 39, 10.02.2009, p. 1) now applies equally to exports into EU member states as well.

15 Para. 23(5) CPPA.

16 It is interesting to note that the legislator chose not to introduce a categorisation of goods to be protected, as is done in other Member States (e.g. a general trade ban on archaeological goods, no rex extra commercium, etc).
} 


\section{DEBUTS}

Paul Fabel

enshrined in the Kulturgüterrückgabegesetz, ${ }^{17}$ implementing the 1970 UNESCO Convention on the Means of Prohibiting and Preventing the Illicit Import, Export and Transfer of Ownership of Cultural Property. ${ }^{18}$ In the new law, Chapter 4 CPPA outlines the duties when trading in cultural objects. By addressing the circulation of cultural property in general - not just imports - owners of such goods will have to carry out due diligence regardless of the (inter)national character of the sale or the parties involved. This could thus include, for example, a sale of a piece of art located on German soil - possibly having been there before the CPPA's entry into force on 6 August 2016. This aspect has been highly criticized by collectors and auctioneers as being too much of a burden with regards to both provenance research and documentation. ${ }^{19}$ The response of the lawmaker, however, is that this is the only foreseeable way to introduce a "fresh start" in clean, legal trading in cultural property.

\section{Due diligence obligations}

In this text, due diligence obligations are divided into general obligations, meaning those obligations with which everyone must comply, and professional obligations, intended for art market actors, such as dealers and auction houses. Then, additional requirements as to documentation and storage are introduced.

\section{"General" due diligence obligations}

Para. 40(1) CPPA prohibits in general the circulation of cultural property that has been stolen, illegally excavated, or illegally exported..$^{20}$ The latter of these three provisions encompasses consistently the export restrictions or provisions of national laws of a third state that would prohibit such a transfer.

The so-called "general due diligence obligations" in para. 41 CPPA are applicable to everyone, without differentiating between grades of professionalization: para. 41(1) CPPA places the obligation to conduct "due diligence" on whoever "starts circulating" the object, regardless of their level of professionalism. As has been prominently and extensively discussed in recent months, this provision shifts the burden of proof to the seller - or more precisely the "circulator".

17 Gesetz zur Ausführung des UNESCO-Übereinkommens vom 14. November 1970 über Maßnahmen zum Verbot und zur Verhütung der rechtswidrigen Einfuhr, Ausfuhr und Übereignung von Kulturgut [Act of 18 May 2007 Implementing the UNESCO Convention of 14 November 1970 on the Means of Prohibiting and Preventing the Illicit Import, Export and Transfer of Ownership of Cultural Property], BGBI. I S. 757, 2547. 1814 November 1970, 823 UNTS 231.

19 Many prominent articles and interviews have been published concerning this. See also the public expert hearing, 13 April 2016, Bundestag, Cultural Affairs Committee: http://www.bundestag.de/mediathek $/$ ?action=search\&contentArea=details\&offsetStart=6\&id=6725437\&instance=m187\&categorie=Ausschusssitzungen\&mask=search\&lang=de [accessed: 29.04.2016].

20 Para. 40(3) CPPA also prohibits the subsequent trade in cultural property through the "law of obligations" ("Verpflichtungsgeschäft") and, e.g., the transfer of ownership ("Verfügungsgeschäft"), thus including potential third states' nationals or the seller himself trading the object in question, which would worsen the situation of the original creditor. 
The text also includes, in para. 40(4) CPPA, a provision to protect the purchaser of a cultural good which has (under para. 40(1) CPPA) been illegally sold. As a result, a person placing such an object into circulation can only be freed from his or her duty to pay just compensation if he or she can prove that para. 40(1) CPPA was not violated - and that he or she did not act with intent or negligence. Without this provision, the task of providing proof discrediting the seller would fall on the purchaser.

Due diligence must be carried out if there is a "justifiable assumption" 21 that an object could fall within the scope of para. 40(1) CPPA - be it in one, two, or all three of the listed categories. The reference point here is the ever-present notion ${ }^{22}$ of a "reasonable person" ${ }^{23}$ in similar circumstances exercising a "reasonable effort". ${ }^{24}$ Furthermore, it is important to note that the conditions during acquisition must not have changed (meaning, for example, that an illegal excavation is still illegal).

Not surprisingly, these regulations sparked criticism from those active in the art market. Nonetheless it is currently standard practice for anyone with a good moral compass, and interest in maintaining a good reputation, to keep documentation supporting his or her diligent research into provenance, which in turn increases the goods' value. In general terms, the aforementioned obligations do not translate into an increase in the duties of private, commercial and professional traders interested in a clean art market.

\section{"Professional" due diligence obligations}

The legal obligations change, however, if cultural property is circulated on a commercial, professional level, such transfers fall under para. 42 CPPA on professional trading. Interestingly, this applies only to entities whose predominant professional business is trade in cultural goods. Thus, the law does not impose on banks or similar organizations the obligation to exercise stricter due diligence when acquiring objects, because their predominant business is not trade in cultural property. ${ }^{25}$ They would thus be obligated only to comply with the general due diligence obligations laid out in para. 41 CPPA.

Para. 42 CPPA then lists the mandatory steps ${ }^{26}$ which have to be adhered to in order to fulfil the professional due diligence requirements, meaning those which must be borne in mind by said business entities. In conjunction with para. 42(1)

\footnotetext{
21 Para. 41(2) CPPA.
}

22 Compare Article 4(1) and (4) of the 1995 UNIDROIT Convention, or similarly Article 10 sent. 2 Directive 2014/60/EU.

23 Para. 41(2) CPPA.

24 Para. 41(3) CPPA, while the reference point for "reasonable efforts" shall always be seen with regard to the value of the object in question.

25 Gesetzentwurf der Bundesregierung. Entwurf eines Gesetzes zur Neuregelung des Kulturgutschutzrechts [Draft law for the reorganization of the law on cultural property], Deutscher Bundestag Drucksache 18/7456, p. 103 (hereinafter cited as: BT Drucksache 18/7456, p. XX).

26 Para. 42(1) No. 1 (name and address of seller, transporter, buyer or client), No. 2 (description and picture to identify the object), No. 3 (provenience of the cultural object), No. 4 (documents that prove the licit import or export), No. 5 (inquiry to check prohibitions and restrictions regarding import, export, or trade), No. 6 


\section{DEBUTS}

Paul Fabel

sent. 2 CPPA, the law then clarifies which specific obligations need to be adhered to if - and only if - economically reasonable for the business. As a result, if the obligations are not economically reasonable, those contained in numbers 3-6 are excluded. This reservation represents a compromise, wherein the legislator had to give in to claims made by the private sector. Businesses wanted this reservation, based on economic grounds (called economic reasonableness), to serve as a waiver of the stricter due diligence obligations. It is quite clear, however, that the level of effort required will (inevitably) increase with the increasing level of professionalism. ${ }^{27}$

In addition, the professional due diligence obligations do not apply in those circumstances listed in para. 42(2) CPPA, thus excluding the trade in books and publications (though, exempting antiquities) as well as the retail trade of sound or images. Professional due diligence obligations similarly do not apply if the object in question is valued below ECU $2500^{28}$ or if it is $\mathrm{an}^{29}$ archaeological object. ${ }^{30}$ This is an increased threshold, as the earlier value limits were at ECU $1000,{ }^{31}$ hence it is yet another step taken by the government toward offering less strict obligations in the art market.

Young artists and flea market negotiators are thus, in most cases, exempt from these professional due diligence obligations, as their transactions rarely reach ECU 2500. It is important to note that the reference point here for "value" is not a possible offer, but rather the price paid within the German borders or an equivalent estimate. ${ }^{32}$

\section{"Simplified" professional due diligence obligations}

When dealing professionally with cultural objects, due diligence obligations might be simplified or mitigated if the person bringing the item into circulation is the crea-

(inquiry to check if object is registered in publically accessible data bases or archives) and No. 7 (written (or digital) declaration of the alienator or seller that he or she rightfully disposes of the object in question) CPPA. Interestingly, para. 42(1) sent. 2 of the draft law (BT Drucksache 18/7456) listed No. 7 of para. 42(1) apply only if economically reasonable. However, in its statement to this draft law, the German upper chamber, the Bundesrat, during its $940^{\text {th }}$ session of December 18,2015 , moved to exclude this number from waiver, thus making it a mandatory due diligence obligation for professional businesses (BT Drucksache 18/7456, p. 153). Inasmuch as the government, in its reply, agreed to these changes and they have not been amended during the last parliamentary hearing (Beschlussempfehlung und Bericht des Ausschusses für Kultur und Medien zum Gesetzesentwurf der Bundesregierung Drucksache 18/7456 [Recommendation for Decision and Report by the Committee on Culture and the Media regarding the Draft Law], Drucksache 18/8908, p. 47 (hereinafter cited as BT Drucksache 18/8908, p. XX), a seller's declaration will be mandatory regardless of the trader's economic capabilities.

27 BT Drucksache 18/7456, p. 98.

28 Para. 42(3) No. 2 CPPA.

29 Previous discussions included a starting value of ECU 100 for archaeological objects, which was then dropped in the final draft: tiny objects valued below ECU100 are crucial in the context of excavations, and also bigger pieces could be split up into smaller ones to be reassembled and re-sold for higher prices while circumventing customs and this law.

30 Para. 42(3) No. 1 CPPA.

31 Para. 18 Kulturgüterrückgabegesetz (BGBI. I S. 757, 762 (2547)).

32 Para. 42 sent. 3 CPPA. 
tor, the manufacturer, or the artist of the object in question him/herself. ${ }^{33}$ The same goes for anyone having purchased from the latter and wishing to resell, ${ }^{34}$ or his or her direct agents, or any other person selling the object in his or her name. ${ }^{35}$ In that case, para. 43 sent. 2 CPPA lists "simplified" professional due diligence obligations, being those combining paras. 41 and 42(1) No. 1-2 CPPA.

Simplified due diligence requirements might also apply to cases under paras. 42(2) and (3) CPPA. If an item falls under either of these two categories (e.g. a retail book), only the "general" due diligence obligations according to para. 41 CPPA apply. ${ }^{36}$

\section{"Increased" professional due diligence obligations}

There are circumstances when 'increased' professional due diligence obligations apply and it is not possible to claim a due diligence waiver based on the concept of economic reasonableness. Increased obligations apply when dealing with Nazi-looted art with an unclear provenance; ${ }^{37}$ when the object originates from a country for which the International Council of Museums (ICOM) has issued a red list; ${ }^{38}$ or if a trade ban imposed by a EU regulation is applicable. ${ }^{39}$ In such cases value limits are irrelevant. ${ }^{40}$

\section{Recordkeeping requirements}

As a next step, the law then lists more precise requirements regarding documentation of the obligations outlined above. Inasmuch as para. 42(1) CPPA already states the kind of information that needs to be acquired; this paragraph now addresses the option to store this information digitally, ${ }^{41}$ and the duty to store it for at least 30 years. ${ }^{42}$ If other legal provisions require the possessor to collect similar or additional information, para. 45(3) CPPA states that its provisions are without prejudice, meaning that as long as the clear identification of an object and its provenance is given in accordance with para. 42 CPPA, it will be sufficient. In this way the law recognizes the standards set out in other parts of German law as sufficient, so long

\footnotetext{
33 Para. 43 sent. 1(1) CPPA.

34 Para. 43 sent. 1(2) CPPA.

35 Para. 43 sent. 1(3) CPPA.

36 Para. 43 sent. 3 CPPA.

37 Para. 44 sent. 1 CPPA.

38 Para. 44 No. 2 CPPA. As of the time of last edit of this contribution, this includes 15 countries. To inquire online, see: http://icom.museum/resources/red-lists-database [accessed: 19.08.2016].

39 Para. 44 No. 3 CPPA. Namely, Council Regulation (EC) No. 1210/2003 of 7 July 2003 concerning certain specific restrictions on economic and financial relations with Iraq and repealing Regulation (EC) No. 2465/96 (OJ L 169, 8.07.2003, p. 6); as well as Council Regulation (EU) No. 1332/2013 of 13 December 2013 amending Regulation (EU) No. 36/2012 concerning restrictive measures in view of the situation in Syria (OJ L 335, 14.12.2013, p. 3).
}

40 BT Drucksache 18/7456, p. 100.

41 Para. 45(1) CPPA.

42 Para. 45(2) CPPA. 


\section{DEBUTS}

Paul Fabel

as the standards in this legislation are upheld. This paragraph applies only to professional dealing, not individuals buying or selling single objects. ${ }^{43}$

As previously stated, the critics of the draft text included mostly businesses that feared these recordkeeping requirements. In their view, both the variety of information to be researched as well as the required length of time such information must be stored exceeds previous limits, thus making it more costly to conduct a proper research. However, because the value of cultural object(s) steadily increases when accompanied by provenance and proof of recent purchases documents, both sides of a transfer should be intrinsically interested in keeping these records. Moreover, receipts validating a purchase that traces back several decades significantly increase both the value of the object(s) and the reputation of the dealer. Thus maintaining such proof should be of genuine interest and should not be too costly in comparison to the increased value of the object, bearing in mind that digital storage does not require much additional space or manpower to an existing business' infrastructure. Especially when stored digitally, keeping the information for either a short period of time or for 30 years does not require a significant extra amount of effort or maintenance.

\section{Implementation and legal consequences}

It is the duty of professional, commercial traders to present to the competent authorities the information requested by them in the execution of their tasks and duties aimed at securing a clean and legal art market. Thus, whenever an object begins circulating in the art market, the dealer must, upon request, be able to present to the authorities the information that he or she has gathered with respect to the provenance of the object - be it "merely" in accordance to para. 41(1) CPPA ${ }^{44}$ (since the stricter diligence requirements did not apply earlier), or in accordance to para. 45(1) CPPA, ${ }^{45}$ as more obligatory research after the entry-into-force of this law must be carried out.

In order to facilitate this process of administrative inquiry into the art market, immediate access must be granted, without prior consultation with the competent trade or labour supervisory inspectorates. ${ }^{46}$ In accordance with this more stringent approach, increasing and recurring violations of the above paragraphs shall no longer be considered merely an administrative offence. ${ }^{47}$ Para. 47 CPPA introduces the possibility of having to face sanctions under para. 35 Gewerbeordnung (GewO, German Trade Regulation Act). ${ }^{48}$ Para. 83 CPPA introduces penal sanctions of up to five years imprisonment, or a fine for the subsequent trade in cultural property

\footnotetext{
43 BT Drucksache 18/7456, p. 107.

44 Para. 46(1) No. 2 CPPA.

45 Para. 46(1) No. 1 CPPA.

46 Para. 46 sent. 2 CPPA.

47 As was the case in the previous law's provisions, para. 20 Kulturgüterrückgabegesetz. 
registered as a cultural object under para. 21 CPPA.${ }^{49}$ If the due diligence obligations under para. 42(1) CPPA have not been met, or not timely met, fines under administrative procedures can reach up to ECU $100,000 .^{50}$

If a third party, most likely the original owner of an object, requests the return of an object in the competent courts, only the courts can request the disclosure of the stored documents and information from the trader in question if the request involves professionally traded art. The access rights arising from para. 48 CPPA then obligate the seller (or rather the person "bringing into circulation" the object) to present the required proof of provenance research and information on the object.

In cases in which member states, or state parties to other international treaties, issue a request for return or restitution through diplomatic channels, this process can be carried out without the necessity of having a court issue the above-mentioned request. ${ }^{51}$ The same is true for Nazi-looted $\operatorname{art}^{52}$, guaranteeing compliance with the Washington Principles. ${ }^{53}$

The criticism remains that this mechanism does not proactively favour restitution by German authorities in general, let alone introduce an overall commandment for restitution in cases in accordance with para. 48(2) CPPA, based on the German saying that "where there's no plaintiff, there's no judge".

\section{Concluding remarks}

It is generally agreed that the new German legislation constitutes a milestone in cultural property protection laws, be it in Germany's national legislative history or in comparison to the legal regimes of third states. Through its implementation of the EU directive, the German legislator has given an impetus to increased provenance research when importing or buying art. The German law increases the duties of whoever starts circulating objects, vesting the burden of proof in the seller. The legislator has chosen to approach the circulation of cultural goods in a general manner, which means that the provisions apply to any future transaction, not merely imports into Germany. Given that the due diligence requirements differentiate between the level of professional involvement as well as the history and/or origin of the item in question, it is the view of this author that the new legislation represents a reasonable compromise. General due diligence obligations encompass almost any natural or legal person involved in a market transaction, and give way to stricter rules if sales are conducted professionally. Depending on a variety of factors, stricter or softer professional requirements need to be fulfilled. However, insofar as these requirements

\footnotetext{
49 Para. 40(3) in conjunction with para. 21 CPPA.

50 Para. 84 CPPA.

51 Para. 48(2) No. 1 CPPA.

52 Para. 48(2) No. 2 CPPA.

53 Washington Conference Principles on Nazi-Confiscated Art, 3 December 1998, available at https:// www.state.gov/p/eur/rt/hlcst/122038.htm [accessed: 25.11.2016].
} 


\section{DEBUTS}

Paul Fabel

apply predominantly only to professional businesses, as outlined above, and in addition might be waived on the basis of economic reasonableness, doubts remain whether the law will have the promised impact on the black market. Still, the law should lead to more scrutiny and better documentation, based on its stricter enforcement provisions, including fines and possibly imprisonment. In the end however, only the future will tell if this will lead to a decrease in illicitly trafficked cultural goods.

\section{References}

Beschlussempfehlung und Bericht des Ausschusses für Kultur und Medien zum Gesetzesentwurf der Bundesregierung Drucksache 18/7456 [Recommendation for Decision and Report by the Committee on Culture and the Media regarding the Draft Law], Drucksache 18/8908, 22.06.2016.

Commission Européenne: Document de travail des services de la commission. Analyse d'impact, SWD (2013) 188 final.

Council Directive 93/7/EEC of 15 March 1993 on the return of cultural objects unlawfully removed from the territory of a Member State, OJ L 74, 27.03.1993, p. 74.

Council Regulation (EC) No. 1210/2003 of 7 July 2003 concerning certain specific restrictions on economic and financial relations with Iraq and repealing Regulation (EC) No. 2465/96, OJ L 169, 8.07.2003, p. 6.

Council Regulation (EC) No. 116/2009 of 18 December 2008 on the export of cultural goods (codified version), OJ L 39, 10.02.2009, p. 1.

Council Regulation (EU) No. 1332/2013 of 13 December 2013 amending Regulation (EU) No. 36/2012 concerning restrictive measures in view of the situation in Syria, OJ L 335, 14.12.2013, p. 3.

Directive 2014/60/EU of the European Parliament and of the Council of 15 May 2014 on the return of cultural objects unlawfully removed from the territory of a Member State and amending Regulation (EU) No. 1024/2012, OJ L 159, 28.05.2014, p. 1.

Gesetz zur Ausführung des UNESCO-Übereinkommens vom 14. November 1970 über Maßnahmen zum Verbot und zur Verhütung der rechtswidrigen Einfuhr, Ausfuhr und Übereignung von Kulturgut [Act of 18 May 2007 Implementing the UNESCO Convention of 14 November 1970 on the Means of Prohibiting and Preventing the Illicit Import, Export and Transfer of Ownership of Cultural Property], BGBI. I S. 757, 2547.

Gesetz zur Neuregelung des Kulturgutschutzrechts - KGSG [Act of 31 July 2016 Reforming the Law on the Protection of Cultural Property], Bundesgesetzblatt (BGBI.) 2016 I S. 1914, entered into force on 6 August 2016, http://www.gesetze-im-internet.de/kgsg/ index.htm [accessed: 21.09.2016].

Gesetzentwurf der Bundesregierung. Entwurf eines Gesetzes zur Neuregelung des Kulturgutschutzrechts [Draft law for the reorganization of the law on cultural property], Deutscher Bundestag 18/7456, 3.02.2016.

Gewerbeordnung in der Fassung der Bekanntmachung vom 22. Februar 1999 [German Trade Regulation Act as published on 22 February 1999], BGBI. I S. 202, as amended.

http://icom.museum/resources/red-lists-database [accessed: 19.08.2016].

http://www.bundestag.de/mediathek/?action=search\&contentArea=details\&offsetStart $=6 \& \mathrm{id}=6725437 \&$ instance $=\mathrm{m} 187 \&$ categorie $=$ Ausschusssitzungen $\&$ mask $=$ search\&lang=de [accessed: 29.04.2016].

UNESCO Convention on the Means of Prohibiting and Preventing the Illicit Import, Export and Transfer of Ownership of Cultural Property, 14 November 1970, 823 UNTS 231.

UNIDROIT Convention on Stolen or Illegally Exported Cultural Objects, 24 June 1995, 34 ILM 1322.

Washington Conference Principles on Nazi-Confiscated Art, 3 December 1998, available at https://www.state.gov/p/eur/rt/hlcst/122038.htm [accessed: 25.11.2016]. 